\title{
RECEPTOR AUTORADIOGRAPHY IN THORACIC SPINAL CORD: CORRELATION OF NEUROTRANSMITTER BINDING SITES WITH SYMPATHOADRENAL NEURONS ${ }^{1}$
}

\author{
VIRGINIA S. SEYBOLD ${ }^{2}$ AND ROBERT P. ELDE \\ Department of Anatomy, University of Minnesota, Minneapolis, Minnesota 55455 \\ Received January 25, 1984; Revised March 26, 1984; Accepted March 29, 1984
}

\begin{abstract}
Receptor autoradiography was combined with the retrograde labeling of sympathoadrenal neurons by fast blue to determine whether opiate, serotonin, catecholamine, or cholinergic binding sites could be spatially correlated with preganglionic neurons in the rat intermediolateral cell column (IML) that project to the adrenal gland. $\left[{ }^{3} \mathrm{H}\right]$ Dihydromorphine (DHM) was used for the visualization of $\mu$ opiate receptors, $\left[{ }^{3} \mathrm{H}\right] l y s e r g i c$ acid diethylamide (LSD) for serotonin receptors, $\left[{ }^{3} \mathrm{H}\right]$ para-aminoclonidine (pAC) for $\alpha_{2}$-adrenergic receptors, and $\left[{ }^{3} \mathrm{H}\right]$ quinuclidinyl benzilate (QNB) for muscarinic cholinergic receptors. While qualitative assessment of autoradiograms indicated that $\alpha_{2}$-adrenergic and muscarinic receptors were concentrated in the intermediate zone of the spinal cord, quantitation of grains in specific regions of the intermediate gray revealed that $\alpha_{2}-$ adrenergic and serotonergic receptors were more highly concentrated over sympathoadrenal preganglionic neurons than over other regions in IML or the adjacent intermediate gray matter.

Information concerning the distribution of neurotransmitter-binding sites in other regions of thoracic spinal cord was also obtained. All ligands showed relatively dense binding sites in the superficial laminae of the dorsal horn, and all but $\left[{ }^{3} \mathrm{H}\right] \mathrm{DHM}$ revealed similar densities of binding sites in the region adjacent to the central canal. Only $\left[^{3} \mathrm{H}\right] \mathrm{QNB}$ revealed a high density of binding sites in the ventral horn of the spinal cord.
\end{abstract}

The intermediolateral cell column (IML) of the thoracic and upper lumbar spinal cord of mammals contains sympathoadrenal preganglionic neurons which project to the medulla of the adrenal gland (Cummings, 1969; Maycock and Heslop, 1979; Schramm et al., 1975). While transmitter(s) released from terminals of preganglionic fibers in the adrenal medulla have a direct effect on chromaffin cell secretion, activity in the preganglionic fibers is determined at the level of their cell bodies in IML by the integration of synaptic inputs.

Several neurotransmitters have been implicated in the regulation of sympathoadrenal neurons. A role for descending monoaminergic systems, including serotonin-, dopamine-, and norepinephrine-containing neurons and cholinergic neurons, is indicated by the ability of these systems to alter adrenal medullary function by virtue of their effects at the level of the spinal cord (Lewander et al., 1977; Quik and Sourkes, 1977; Gauthier et al., 1979; Gagner et al., 1983). The neuronal connections within IML which underlie regulation of activity of sympathoadrenal neurons, however, have not been determined. Previous work in this laboratory combined two morphological techniques to address specifically the relationship of chemically

${ }^{1}$ This work was supported by United States Public Health Service Grants DA 02148 and NS 17702 . We wish to thank Michael Frey and Joan Shaughnessey for their technical assistance in the execution of these studies.

${ }^{2}$ To whom correspondence should be addressed. coded afferents to sympathoadrenal neurons. Using immunohistochemistry in conjunction with the retrograde transport of a fluorescent dye to identify neurons in IML that innervate the adrenal gland, substance P-, enkephalin-, somatostatin-, and serotonin-containing fibers were observed in apposition to sympathoadrenal neurons (Holets and Elde, 1982). Although a synaptic relationship between these elements remains to be confirmed at the ultrastructural level, these results may provide a morphological basis for a role of these transmitters in the regulation of sympathoadrenal neurons.

The present studies were undertaken to gain insights into pathways regulating adrenal medullary function from the perspective of neurotransmitter receptor populations. By combining receptor autoradiography with retrograde labeling of sympathoadrenal neurons, we sought to determine whether opiate, serotonin, catecholamine, or muscarinic receptors could be spatially correlated with preganglionic neurons in the rat IML that project to the adrenal gland. The studies also provided a comparison of the distribution of four receptor populations in the thoracic spinal cord, a region of the neuroaxis frequently neglected in the sampling for large mapping studies.

\section{Materials and Methods}

\section{Retrograde labeling of sympathoadrenal neurons with fast blue}

The data in this study were collected from spinal cord tissues of four male Sprague-Dawley rats ( 160 to $200 \mathrm{gm}$ ) whose left adrenal glands were injected with fast blue. Under chloral hydrate anesthesia (350 
$\mathrm{mg} / \mathrm{kg}$ ), a midflank incision was made to expose the left adrenal gland of each animal. A micromanipulator was used to hold a 50- $\mu$ l Hamilton syringe containing the fast blue suspension (1\% in distilled water), and the syringe was fitted with a 30 gauge needle. The needle was inserted into the adrenal medulla such that the bevel of the needle was directed toward the hilus, where the peripheral nerves enter the gland. Once the needle was in place, 5 to $10 \mu \mathrm{l}$ of fast blue were injected into the gland over a 15 -min period, and an additional $15 \mathrm{~min}$ were allowed to lapse before the needle was withdrawn to allow for dissipation of the injection volume into the gland. The wound was then closed, and the animals were allowed to recover.

After a 5-day survival period, the spinal cord from each animal was taken for histology. Each animal was again anesthetized with chloral hydrate, and the ascending aorta was cannulated transcardially with a bulbous needle. The vasculature was rinsed with $50 \mathrm{ml}$ of ice-cold saline followed by $150 \mathrm{ml}$ of ice-cold $0.1 \%$ paraformaldehyde in $0.1 \mathrm{M}$ phosphate buffer, $\mathrm{pH} \mathrm{7.4,} \mathrm{to} \mathrm{achieve} \mathrm{a} \mathrm{light} \mathrm{fixation.} \mathrm{Spinal} \mathrm{cord} \mathrm{segments}$ $\mathrm{T} 7$ to $\mathrm{T} 10$ were rapidly removed in two pieces and frozen in brain paste. Previous studies showed that these spinal segments contain approximately two-thirds of the sympathoadrenal neurons in rats (Schramm et al., 1975; Holets and Elde, 1982).

For visualization of fast blue-labeled neurons and subsequent ligand binding, serial $10-\mu \mathrm{m}$ cryostat sections were cut in a horizontal plane through the spinal cord segments and thaw-mounted onto acid-washed, gelatin-coated glass slides. The distribution of the IML neurons retrogradely labeled with fast blue was visualized in dry tissue sections by fluorescence microscopy, using transmitted UV illumination with a UG1 excitation filter and a 41 barrier filter. Since the fast blue was not retained in the sections during the radiohistochemical procedure, a permanent record of the location of fast blue-labeled cells in each section with respect to the perimeter of the tissue was prepared with an X-Y stage digitizer and plotter (Minnesota DataMetrics, MD-1). It was not possible, in practice, to make truly horizontal cuts through the length of the IML, so the slightly oblique sections through this region resulted in fast blue-labeled cells being present in many sections. Only sections with a minimum of 12 labeled cells were used in the subsequent autoradiographic studies. These sections were stored frozen in sealed boxes with a drying compound for 7 to 17 weeks before incubation with radiolabeled ligands. There was no apparent loss of ligand binding over this time period.

\section{Characterization of ligand binding on tissue sections}

Four radiolabeled ligands, each specific for a different transmitterbinding site, were used in these studies: $\left[{ }^{3} \mathrm{H}\right]-p$-aminoclonidine $\left(\left[{ }^{3} \mathrm{H}\right]\right.$ $\mathrm{pAC}$, an $\alpha_{2}$-adrenergic receptor agonist $),\left[{ }^{3} \mathrm{H}\right]$ dihydromorphine $\left(\left[{ }^{3} \mathrm{H}\right]\right.$ DHM, a $\mu$ opiate receptor agonist $),\left[{ }^{3} \mathbf{H}\right]$ lysergic acid diethylamide $\left(\left[{ }^{3} \mathbf{H}\right]\right.$ LSD, a serotonin receptor antagonist), and $\left[{ }^{3} \mathrm{H}\right]$ quinuclidinyl benzilate ([ $\left.{ }^{3} \mathrm{H}\right] \mathrm{QNB}$, a muscarinic receptor antagonist). The binding characteristics of each of these ligands have been described by others using histological sections in vitro $\left(\left[{ }^{3} \mathrm{H}\right] \mathrm{pAC}\right.$ : Young and Kuhar, $1979 \mathrm{~b} ;\left[{ }^{3} \mathrm{H}\right]$ DHM: Young and Kuhar, 1979b; $\left[{ }^{3} \mathrm{H}\right] \mathrm{LSD}$ : Meibach et al., 1980; $\left[{ }^{3} \mathrm{H}\right]$ QNB: Wamsley et al., 1981), and we used comparable conditions to reproduce their results.

Although each ligand was incubated in a different buffer, the binding protocols for the ligands had several features in common. Each protocol included an initial 10-min incubation in pre-incubation buffer (defined below for each ligand) at $22^{\circ} \mathrm{C}\left(\left[{ }^{3} \mathrm{H}\right] \mathrm{DHM},\left[{ }^{3} \mathrm{H}\right] \mathrm{QNB}\right.$ with the addition of $100 \mathrm{mM} \mathrm{NaCl})$ or $37^{\circ} \mathrm{C}\left(\left[{ }^{3} \mathrm{H}\right] \mathrm{pAC},\left[{ }^{3} \mathrm{H}\right] \mathrm{LSD}\right)$ and two 5 -min washes in buffer at $22^{\circ} \mathrm{C}$ to enhance removal of endogenous ligands from the tissue. Following this pre-incubation, the tissue sections were incubated with the radiolabeled ligand, rinsed two times for $5 \mathrm{~min}$ in buffer at $4^{\circ} \mathrm{C}$, and then quickly dipped in distilled water $\left(4^{\circ} \mathrm{C}\right.$ ) before wiping (for in vitro studies) or drying under a stream of cooled, dried air (for preparation of autoradiograms).

The following buffers and incubation times were determined to yield maximum specific binding for individual radiolabeled ligands and were used to determine affinity constants and prepare tissues for autoradiograms.

$\left[{ }^{3} H\right] p A C$. The pre-incubation buffer of $50 \mathrm{mM}$ Tris, $\mathrm{pH} 7.4$, was modified by the inclusion of $0.1 \%$ ascorbate, $0.05 \%$ bacitracin, and 10 $\mu \mathrm{M}$ pargyline for ligand binding, and the addition of $100 \mu \mathrm{M}$ norepinephrine was used to determine nonspecific binding. Incubation time in radiolabeled ligand was $60 \mathrm{~min}$ at $22^{\circ} \mathrm{C}$.

$\left[{ }^{3} H\right] D H M$. The pre-incubation buffer of $170 \mathrm{~mm}$ Tris, $\mathrm{pH}$ 7.4, with $1 \mathrm{~mm}$ dextrorphan was used throughout the procedure. The opiate antagonist levallorphan $(10 \mu \mathrm{M})$ was used to determine nonspecific binding. The tissues were incubated with $\left[{ }^{3} \mathrm{H}\right] \mathrm{DHM}$ for $30 \mathrm{~min}$ at $22^{\circ} \mathrm{C}$ in an opaque container due to the reported photosensitivity of the drug.

$\left[{ }^{3} H\right] L S D$. The pre-incubation buffer of $300 \mathrm{mM}$ Tris-maleate, $\mathrm{pH}$ 7.4 , was modified by the addition of $0.1 \%$ ascorbate, $0.05 \%$ bacitracin, $10 \mu \mathrm{M}$ pargyline, and $1 \mu \mathrm{M}$ haloperidol for radiolabeled ligand binding. Since LSD is reported to have equal affinity for serotonin and dopamine receptors (Burt et al., 1976), and preliminary studies indicated that haloperidol displaced $6 \%$ of the total LSD binding, haloperidol was included in the buffer with the $\left[{ }^{3} \mathrm{H}\right] \mathrm{LSD}$ to avoid confusion of results with dopamine receptors. For determination of nonspecific binding, $100 \mu \mathrm{M}$ serotonin was added. Tissues were incubated for $60 \mathrm{~min}$ at $22^{\circ} \mathrm{C}$ with $\left[{ }^{3} \mathrm{H}\right] \mathrm{LSD}$.

$\left[{ }^{3} H\right] Q N B$. The pre-incubation buffer of $50 \mathrm{~mm}$ potassium phosphate, $\mathrm{pH} 7.4$, was used throughout the binding protocol. Atropine $(1 \mu \mathrm{M})$ was used for determination of nonspecific binding. Tissues were incubated in radiolabeled ligand for $30 \mathrm{~min}$ at $22^{\circ} \mathrm{C}$.

Studies to determine association and dissociation rates and affinity constants were carried out on $10-\mu \mathrm{m}$ coronal sections described above. Slides bearing two sections each were incubated in triplicate for determination of total and nonspecific binding for each variable. At the end of the last wash, tissues were wiped from the slides with a glass filter disc. The discs were placed individually in scintillation vials with 0.5 $\mathrm{ml}$ of buffer and $10 \mathrm{ml}$ of Aquasol (New England Nuclear Corp.) for liquid scintillation spectroscopy. Affinity constants were determined from Scatchard plots of data for five to seven concentrations of ligand.

\section{Preparation of autoradiograms}

Spinal cord sections were incubated in the following ligand concentrations for subsequent preparation of autoradiograms: $\left[{ }^{3} \mathrm{H}\right] \mathrm{pAC}, 2.5$ nM; $\left[{ }^{3} \mathrm{H}\right] \mathrm{DHM}, 5 \mathrm{nM} ;\left[{ }^{3} \mathrm{H}\right] \mathrm{LSD}, 6 \mathrm{nM}$; and $\left[{ }^{3} \mathrm{H}\right] \mathrm{QNB}, 0.5 \mathrm{nM}$. Thus, each of the ligands with the exception of DHM was used at or below its calculated $K_{D}$ in preparing autoradiograms. The higher concentration of DHM used here produced a higher total binding with no decrease in percentage of specific binding. Pairs of adjacent sections were selected for total binding and nonspecific binding conditions so that specific binding could be inferred from counting grains at the same coordinates in adjacent tissue sections.

Autoradiograms of spinal cord sections were prepared by following the technique originally described by Young and Kuhar (1979a) using NTB-3 nuclear emulsion (Kodak) diluted 1:1 with water. The emulsioncoated coverslip approach allowed us to maintain a one-to-one relationship between the autoradiogram and coordinates within each tissue section. Exposure times were QNB, 4 weeks; pAC, 6 weeks; and DHM and LSD, 8 weeks.

\section{Analysis of autoradiograms}

Autoradiograms were photographed with darkfield illumination, and quantitative data were obtained by counting grains per $1600 \mu \mathrm{m}^{2}$ using a grid reticle in the microscope. The X-Y stage digitizer and maps of fast blue-labeled cells for each tissue section were used to find the position over fast blue-labeled cells in the autoradiograms. Twentyfour $1600-\mu \mathrm{m}^{2}$ areas were counted in each total binding autoradiogram: eight areas corresponding to fast blue-labeled (sympathoadrenal) cells in IML, eight other areas in the IML that were devoid of fast bluelabeled cells, and eight areas $160 \mu \mathrm{m}$ medial to fast blue-labeled cells (i.e., in the intermediate gray matter, IMG). Because of the oblique sections through the IML nucleus, the distribution of fast blue-labeled cells was used to define the nucleus, and counts for other regions in the IML were made within $200 \mu \mathrm{m}$ rostral or caudal to fast blue-labeled cells. To assess specific binding, the same coordinates were counted on the autoradiogram of the adjacent section which had been incubated with excess cold ligand to determine nonspecific binding. Statistical analyses were done on the grain counts reflecting specific binding (total minus nonspecific counts for each tissue coordinate).

\section{Statistical analyses}

Scatchard analysis was used to determine the affinity constant of each ligand. Differences in specific binding among groups were determined by the Kruskal-Wallis analysis of variance by ranks, and individual comparisons were made at the $p<0.05$ level. 


\section{Chemicals}

Biochemicals used in these studies were obtained from the following sources: dextrorphan tartrate, levallorphan tartrate, Hoffman-IaRoche; fast blue (253/50), Dr. Illing, K. G. Makromolekulare Chemie, Gro $\beta$-Umstadt, Federal Republic of Germany; haloperidol, McNeil; $\left[{ }^{3} \mathrm{H}\right] \mathrm{pAC}(10 \mathrm{Ci} / \mathrm{mmol}),\left[{ }^{3} \mathrm{H}\right] \mathrm{DHM}(70 \mathrm{Ci} / \mathrm{mmol}),\left[{ }^{3} \mathrm{H}\right] \mathrm{LSD}(48 \mathrm{Ci} /$ $\mathrm{mmol})$, and $\left[{ }^{3} \mathrm{H}\right] \mathrm{QNB}(40 \mathrm{Ci} / \mathrm{mmol})$, New England Nuclear; pargyline hydrochloride, Saber Laboratories; atropine sulfate, bacitracin, norepinephrine hydrochloride, and serotonin creatinine sulfate, Sigma Chemical Co.

\section{Results}

Characteristics of ligand binding. The results of biochemical studies of the binding of each of the ligands to brain tissue sections are shown in Table I. The affinity constant $\left(K_{D}\right)$ of each ligand fell in the nanomolar range, with QNB exhibiting the greatest and LSD the lowest affinities of the four ligands. By liquid scintillation spectroscopy, the percentage of specific binding for each of the ligands ranged from almost $100 \%$ for QNB to approximately 50\% specific binding for DHM and LSD. These values were closely correlated with the grain counts over the gray matter of the spinal cord in autoradiograms prepared from radiolabeled ligand alone and radiolabeled ligand plus an excess of cold ligand.

Distribution of ligand binding in the thoracic spinal cord by autoradiography. By comparison of gray matter to white matter (Fig. 1, Table II), all of the radiolabeled ligands produced a diffuse grain pattern over the gray matter of the spinal cord, including the region of the IML. In addition, binding of each of the ligands resulted in patterns of higher grain densities in specific regions of the gray matter.

The autoradiograms reflecting $\left[{ }^{3} \mathrm{H}\right] \mathrm{pAC}$ binding in thoracic spinal cord (Figs. $1 A$ and $2 A$ ) showed notable densities of grains in three regions. The highest density appeared in the superficial laminae of the dorsal horn, and moderate to high densities of grains were observed in the IML and in the gray matter adjacent to the central canal. The high density of grains in the IML was also apparent in horizontal sections through the cord (Fig. 2A), which showed densities of grains in the intermediate regions of the gray matter at regular, rostrocaudal intervals. Visual comparison of the autoradiograms to their corresponding map of fast blue-labeled cells (Fig. $2 A$ ) indicated an overlap in the distribution of pAC-binding sites and fast blue-labeled cells, but an exclusive correlation between the two population markers did not occur.

Radiolabeled DHM exhibited the most restricted distribution of the four ligands in the rat spinal cord. Autoradiograms of transverse sections showed a high density of grains in the superficial laminae of the dorsal horn (Fig. $1 B$ ), but no other remarkable densities were noted. Inspection of autoradiograms of horizontal sections in conjunction with their corresponding

\section{TABLE I}

Binding characteristics of receptor ligands to tissue sections All binding characteristics were determined on tissue that was lightly fixed with $0.1 \%$ paraformaldehyde as described under "Materials and Methods." Each $K_{D}$ was determined by a Scatchard analysis. Percentage of specific binding was determined by liquid scintillation spectroscopy (LSS) and by counting grains over the gray matter in autoradiograms (ARG).

\begin{tabular}{lcccc}
\hline \multirow{2}{*}{ Tigand } & \multirow{2}{*}{$K_{\boldsymbol{D}}$} & \multirow{2}{*}{$r$} & \multicolumn{2}{c}{ Specific Binding } \\
\cline { 4 - 5 } & & & LSS & ARG \\
\hline & $n M$ & & $\%$ & $\%$ \\
pAC & 2.4 & 0.960 & 82 & 83 \\
DHM & 1.2 & 0.823 & 48 & 46 \\
LSD & 7.7 & 0.968 & 48 & 47 \\
QNB & 1.1 & 0.942 & 97 & 97 \\
\hline
\end{tabular}

maps of the distribution of fast blue-labeled cells (Fig. $2 B$ ) indicated that a high concentration of DHM-binding sites did not occur in the IML.

Binding sites for $\left[{ }^{3} \mathrm{H}\right] \mathrm{LSD}$ in thoracic spinal cord appeared concentrated in two areas of the gray matter (Figs. $1 C$ and $3 A$ ). Moderate grain densities occurred in the superficial laminae of the dorsal horn and in the region adjacent to the central canal. Visually, there was no apparent concentration of grains in the IML in either transverse or longitudinal sections.

The distribution of $\left[{ }^{3} \mathrm{H}\right] \mathrm{QNB}$-binding sites in caudal thoracic spinal segments made an interesting comparison with respect to the other ligands used in the study (Figs. $1 D$ and $3 B$ ). Relatively moderate densities of grains appeared over the superficial laminae of the dorsal horn and in the gray matter adjacent to the central canal, a distribution similar to pAC and LSD. A moderate density of grains also appeared over the IML and the adjacent intermediate gray matter. The most unique feature to the pattern of $\left[{ }^{3} \mathrm{H}\right] \mathrm{QNB}$-binding sites was the high density of grains noted over the ventral and lateral regions of the ventral horn. In horizontal sections (Fig. $3 B$ ) it was apparent that these densities of binding sites occurred in patches along the lateral aspect of the gray matter in a longitudinal dimension. Since the fast blue cells marked the location of the IML, and the regions of intermediate gray matter generally progressed from dorsal to ventral in a rostral to caudal direction through the horizontal sections, it was apparent from Figure $3 B$ that these concentrated QNB-binding sites are not associated with the IML but occur ventral to this nucleus.

Correlation of ligand binding with fast blue-labeled cells. Grain counting afforded greater precision in determining whether there was a correlation in ligand-binding sites within the IML and sympathetic preganglionic neurons that innervate the adrenal gland in particular (Table II). While the data for pAC were consistent with Figure $2 A$ in showing a very significant increase $(p<0.01)$ in grains over fast blue-labeled cells in comparison to other regions in the IML and the adjacent IMG, an important piece of new information emerged. Grain counting documented that LSD-binding sites were approximately $1 \frac{1 / 2}{2}$ times higher over fast blue-labeled cells than over other regions in the IML and more medial areas in the intermediate gray matter $(p<0.05)$. With respect to the other ligands used in the study, the data in Table II largely reflect the qualitative assessment of autoradiograms from their visual examination as described above. DHM and QNB exhibited higher binding in the gray matter than in the white matter, but the binding in the IML (both fast blue-labeled cells and the IML group) was no greater than in the adjacent intermediate gray matter.

\section{Discussion}

This is the first report to our knowledge that compares the distribution of several transmitter-binding sites within a specific region of the spinal cord and relates these binding sites to a particular neuronal circuit of autonomic function. Most published surveys of transmitter-binding sites in rat central nervous system have neglected to consider structural differences in spinal cord as a function of cord level and have usually included data from either the cervical or lumbosacral enlargements. The present study focuses upon the thoracic spinal cord and, in particular, the preganglionic sympathetic column of neurons which are restricted in rats to thoracic and rostal lumbar segments. Furthermore, its description of receptor distributions in thoracic spinal cord supplements the findings of general mapping studies of transmitter-binding sites throughout the neuroaxis that include a sample of cervical or lumbar spinal cord as representative of the spinal cord.

Pharmacological considerations. The ligands and experimental conditions under which they were used resulted in the 


\section{A. pAC}

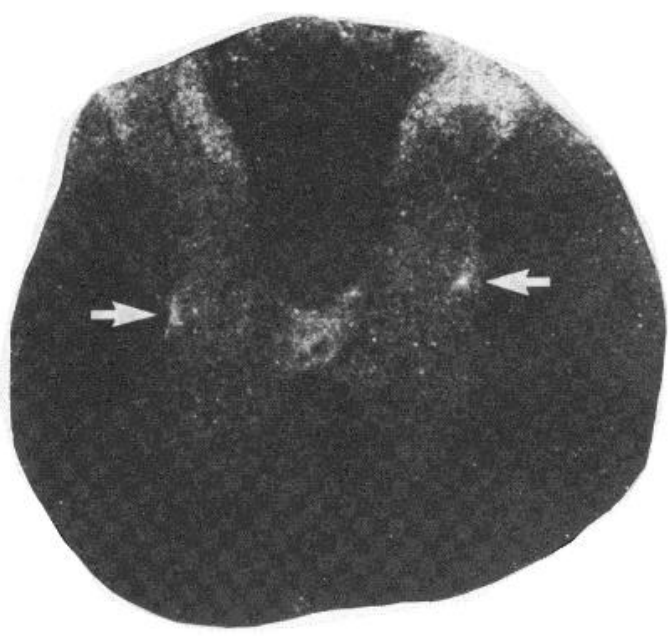

\section{LSD}

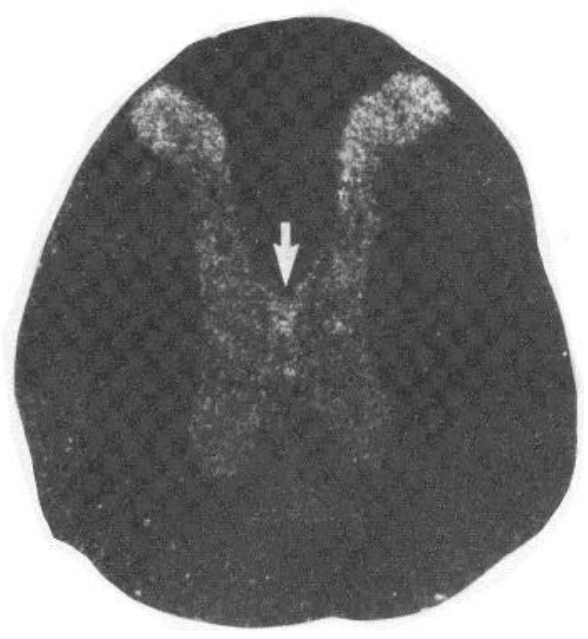

\section{B. DHM}

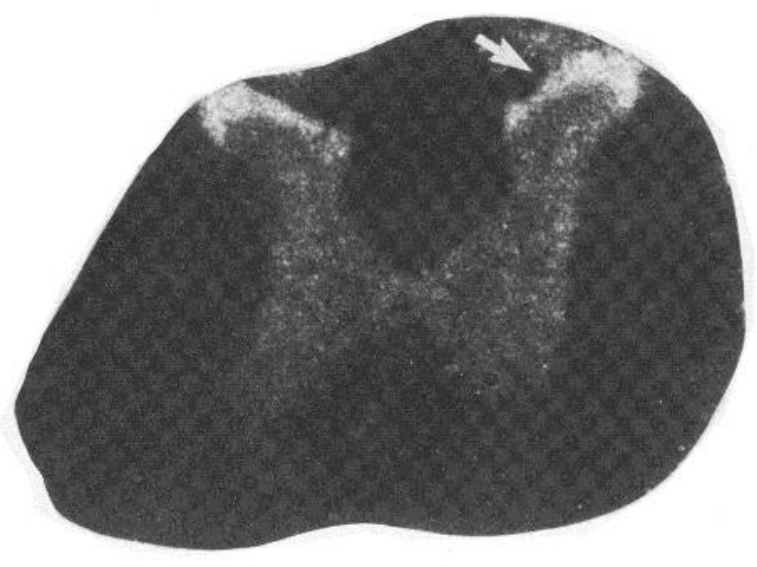

D. QNB

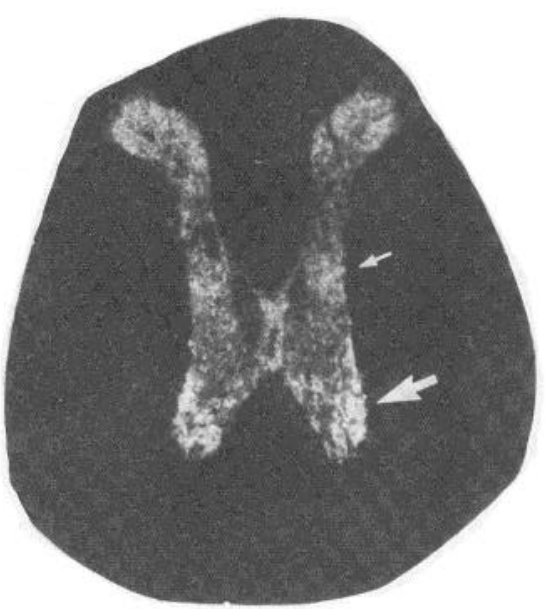

Figure 1. Darkfield photomicrographs of autoradiograms of ${ }^{3} \mathrm{H}$-ligand binding in transverse sections of rat spinal cord. The bar represents 500 $\mu \mathrm{m}$; all micrographs are of equal magnification. A, Autoradiogram of $\left[{ }^{3} \mathrm{H}\right] \mathrm{pAC}$ binding in a section through segment T8. Arrows indicate dense patches of grains in the region of the IML. Dense accumulations of grains are also present in substantia gelatinosa and the region around the central canal. $B$, Autoradiogram of $\left[{ }^{3} \mathrm{H}\right] \mathrm{DHM}$ binding in a section through segment T9. The arrow indicates dense grain pattern in substantia gelatinosa. $C$, Autoradiogram of $\left[{ }^{3} \mathrm{H}\right] \mathrm{LSD}$ binding in a section through segment T7. The arrow indicates grain density in the area around the central canal. Also note density in the region of substantia gelatinosa. $D$, Autoradiogram of $\left[{ }^{3} \mathrm{H}\right] \mathrm{QNB}$ binding in a section through segment T7. The large arrow indicates dense grain pattern in the lateral regions of the ventral horn; the small arrow indicates moderate density of grains in the region of the IML and the IMG. Also note grains around the central canal and in substantia gelatinosa.

selective visualization of four binding sites in rat spinal cord that can be related to pharmacologically characterized receptors sites. pAC is reported to have selective affinity for $\alpha_{2}$-adrenergic receptors in brain (U'Prichard and Snyder, 1979), DHM for $\mu$ opiate receptors (Lord et al., 1977), LSD for serotonergic receptors (Bennett and Snyder, 1975), and QNB for muscarinic receptors (Meyerhofer, 1972). Since there was good agreement between the $K_{D}$ determined for each ligand on sectioned rat brain in the present study and the $K_{D}$ determined on membranes isolated from brain by others (pAC: Rouot and Snyder, 1979; DHM: Wood et al., 1981; LSD: Bennett and Snyder, 1975; QNB: Yamamura and Snyder, 1974; Kayaalp and Neff, 1980), and ligands were used at or below their $K_{D}$ values, it is likely that autoradiograms reflect these classes of receptors. 
TABLE II

Specific binding of ligands in the IMG of rat thoracic spinal cord

\begin{tabular}{llr}
\hline Ligand & \multicolumn{1}{c}{ Region } & \multicolumn{1}{c}{ Grains $^{a}$} \\
\hline pAC & Fast blue cells & $65.9 \pm 5.6(32)^{b}$ \\
& IML & $44.0 \pm 4.6(32)$ \\
& IMG & $35.9 \pm 2.6(31)$ \\
& White matter & $9.9 \pm 0.7(31)$ \\
DHM & Fast blue cells & $67.9 \pm 4.9(32)$ \\
& IML & $69.7 \pm 6.0(32)$ \\
& IMG & $69.4 \pm 5.7(31)$ \\
& White matter & $27.7 \pm 3.0(28)$ \\
LSD & Fast blue cells & $38.5 \pm 3.9(22)^{c}$ \\
& IML & $26.1 \pm 3.0(23)$ \\
& IMG & $28.8 \pm 3.0(21)$ \\
& White matter & $8.4 \pm 1.1(24)$ \\
QNB & Fast blue cells & $218.2 \pm 6.2(31)$ \\
& IML & $202.6 \pm 5.4(30)$ \\
& IMG & $207.3 \pm 6.8(32)$ \\
& White matter & $12.9 \pm 1.6(31)$ \\
\hline
\end{tabular}

a The grain counts represent the specific binding over the regions listed and are expressed as the mean \pm SEM in grains per $1600 \mu \mathrm{m}^{2}$; the number in parentheses is the $N$ for each group.

${ }^{b}$ Statistically different from all other regions in the ligand group at $p<0.01$.

${ }^{c}$ Statistically different from all other regions in the ligand group at $p<0.05$.

However, the binding sites revealed by LSD require further comment. LSD is reported to have a high affinity for spiroperidol-binding sites which have been designated serotonin type2 receptors (Peroutka and Snyder, 1979) in addition to dopamine receptors (Burt et al., 1976). However, an in vitro binding study of rat spinal cord reports an absence of serotonin type-2 receptors (Monroe and Smith, 1983). In light of this report and the inclusion of the dopamine receptor antagonist haloperidol in the incubation buffer in the present study, we believe our results reflect serotonin receptors of the type-1 class (Peroutka and Snyder, 1979).

Although four populations of receptors were localized in the present study, comparisons among ligands of receptor densities in one area are not justified since the studies were not designed to take into account differences in binding affinity, specific activity, and exposure times of the ligands. However, comments concerning differences in grain densities observed among regions of the spinal cord are valid in the discussion of each ligand.

Morphological considerations with respect to grain counts. In interpreting the grain count data, it is important to consider the cytoarchitectural features of the IML and the preganglionic neurons that comprise it. Three cell types have been described in the IML of rat (Schramm et al., 1975; Holets and Elde, 1982), cat (Deuschl and Illert, 1981), and monkey (Petras and Cummings, 1972). For rat, the cell sizes range from small, round cells of generally $12 \mu \mathrm{m}$ in diameter to fusiform and multipolar cells of $8 \times 22 \mathrm{\mu m}^{2}$ in longitudinal sections (Schramm et al., 1975), giving cross-sectional areas of approximately 100 to $170 \mu \mathrm{m}^{2}$. Since this is roughly one-tenth the area counted with the grid reticle, our grain counts will reflect ligand binding over the cell soma and a portion of the proximal dendrites. Only single sympathoadrenal neurons are assumed to be counted within each $1600 \mu \mathrm{m}^{2}$, since the cells were generally aligned in a single row in longitudinal sections of our material, and the cells were spaced by more than $20 \mu \mathrm{m}$. However, the longitudinal orientation of dendrites in the IML and the intertwining that results (Rethelyi, 1972; Schramm et al., 1975) may contribute to overlapping dendritic arbors of two adjacent preganglionic neurons.
While the position of fast blue-labeled cells defined the coordinates for counting grains associated with sympathoadrenal neurons, the coordinates for other preganglionic neurons were not as rigorously established. However, due to the organization of the IML, it is likely that comparable cytoarchitectural structures were included. Although clustering of cells at regular intervals (300 $\mu \mathrm{m}$ in cat; Deuschl and Illert, 1981) along a rostrocaudal axis is a striking feature of the IML, a continuous string of preganglionic neurons is consistently observed in the IML between these clusters (Petras and Cummings, 1972; Rethelyi, 1972; Deuschl and Illert, 1981). Since the longitudinal arrangement of the fast blue-labeled cells in our horizontal sections through the IML was distributed through a distance greater than $300 \mu \mathrm{m}$, the cells accurately reflected the longitudinal distribution of preganglionic neurons in the IML and not just clusters. Therefore, grain counts along this line may be expected to correlate with other preganglionic neurons.

The third group of grain counts was sampled $160 \mu \mathrm{m}$ medial to fast blue-labeled preganglionic neurons (IMG). This region would be associated with autonomic function when fast bluelabeled cells fell in clusters with other preganglionic neurons, since the periodicity of clusters appears to coincide with the periodicity of nucleus intercalatus in the intermediate zone of the spinal cord which also contains preganglionic neurons (Petras and Cummings, 1972; Schramm et al., 1975; Petras and Faden, 1978). However, due to the longitudinal distance over which fast blue-labeled cells were distributed, only a small proportion of the areas counted in this group would be expected to lie over nucleus intercalatus. Therefore, the grain counts over the IMG medial to the IML are not believed generally to represent binding to neuropil associated with autonomic function.

Receptor distribution in the IML and the adjacent intermediate gray. Although all four ligands exhibited some degree of specific binding in the IML and the adjacent intermediate gray matter, the pattern of grain densities within these regions was different for each ligand, suggesting differential localizations to neuronal processes and even among different populations of preganglionic neurons in the IML.

Highly concentrated patterns of grains occurred with $\left[{ }^{3} \mathrm{H}\right]$ pAC binding. While $\alpha_{2}$ receptor sites have been localized both pre- and postsynaptically to date, and there is some evidence that clonidine effects in other regions of the IML may be postsynaptic (i.e., not via receptors on nerve terminals; Connor and Finch, 1981), the densely packed patterns of grains within the IML in horizontal sections and at periods transversely across the intermediate gray matter suggest a location of $\alpha_{2}$ receptors on nerve fibers. In general, the location of these densities was significant over the IML and over sympathoadrenal neurons in particular. The neurotransmitter-containing identity of the nerve fibers remains to be explored. $\alpha_{2}$ receptors have been implicated in the autoregulation of catecholamine fibers, and the distribution of dopamine $\beta$-hydroxylase-immunoreactive fibers in the intermediate gray matter of thoracic cord parallels the banding pattern observed autoradiographically (Glazer and Ross, 1980; Westlund et al., 1983). However, we have observed a similar banding pattern of enkephalinergic and serotonergic fibers in immunohistochemical studies of thoracic spinal cord (V. S. Seybold and R. P. Elde, unpublished observations), which raises the possibility that catecholamines may alter autonomic function partly via a presynaptic interaction with these transmitter systems. A presynaptic effect of catecholamines on other transmitter-containing terminals in the IML may explain why it has been difficult to determine trans-synaptic effects of clonidine on adrenal tyrosine hydroxylase activity (Gagner et al., 1983).

Muscarinic receptor sites were also high in the IML and the intermediate gray matter, although they appeared less densely distributed than binding sites in the ventral horn. The autora- 

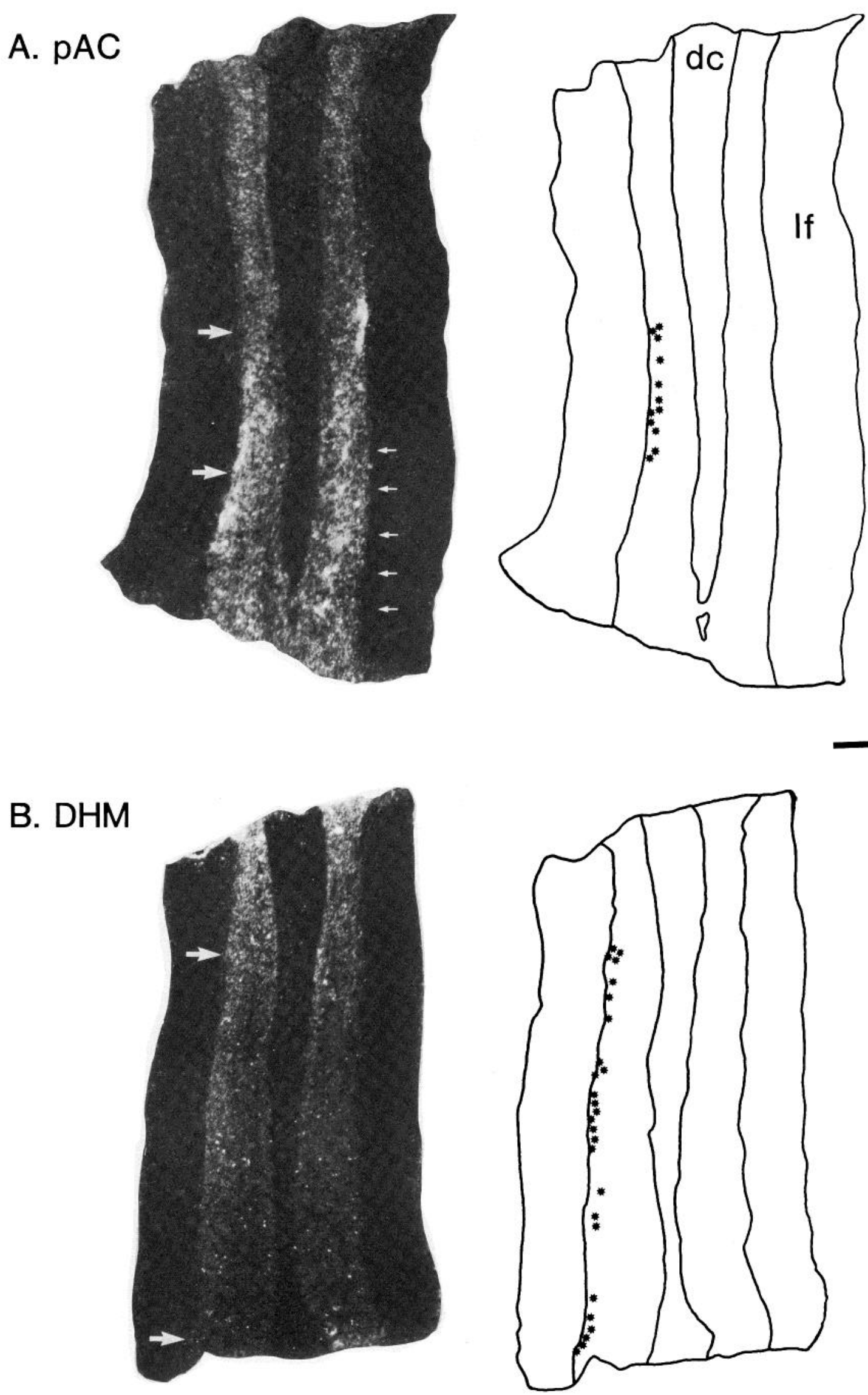

Figure 2. Darkfield photomicrographs of autoradiograms of $\left[{ }^{3} \mathrm{H}\right] \mathrm{pAC}(A)$ and $\left[{ }^{3} \mathrm{H}\right] \mathrm{DHM}$ binding $(B)$ in horizontal sections through rat spinal cord. Each autoradiogram is accompanied by a representation of the computer map recording the location of sympathoadrenal neurons within the tissue section. The large arrows indicate the corresponding longitudinal range of these cells in the photomicrographs. The regions of the dorsal columns $(d c)$ and lateral funiculus $(l f)$ in the horizontal sections are indicated in the map in $A$. The section in $A$ includes spinal segments T7 and T8; $B$ includes segments T9 and T10. The small arrows in $A$ indicate periods of dense patches of grains in the IMG gray matter. The bar represents $500 \mu \mathrm{m}$; figures in $A$ and $B$ are of equal magnification. 

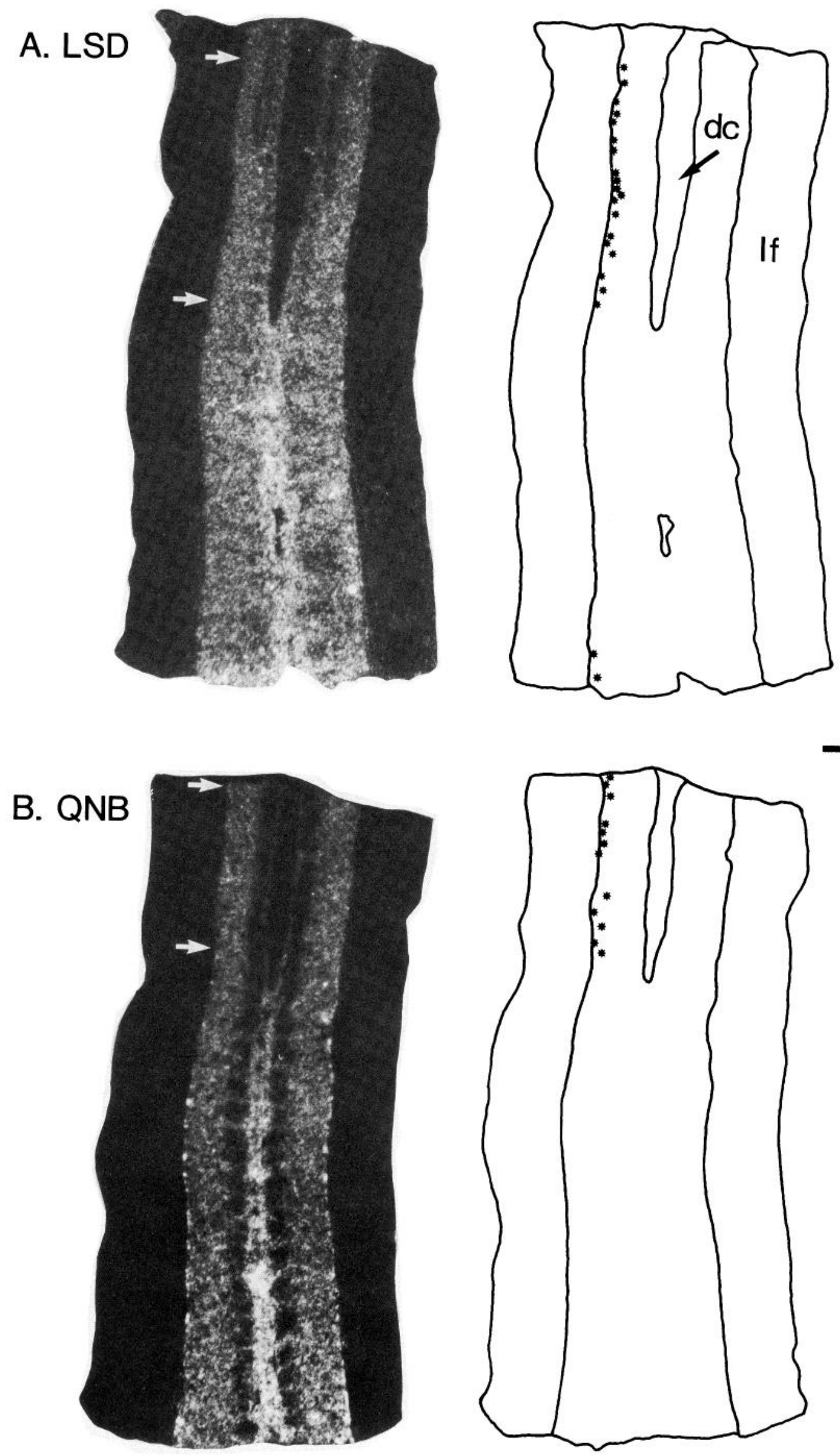

Figure 3. Darkfield photomicrographs of autoradiograms of $\left[{ }^{3} \mathrm{H}\right] \mathrm{LSD}(A)$ and $\left[{ }^{3} \mathrm{H}\right] \mathrm{QNB}(B)$ binding in horizontal sections through rat spinal cord. Each autoradiogram is accompanied by a representation of the computer map recording the location of sympathoadrenal neurons within the tissue section. The large arrows indicate the corresponding longitudinal range of these cells in the photomicrographs. The regions of the dorsal columns $(d c)$ and lateral funiculus $(l f)$ in the horizontal sections are indicated in the map in $A$. Sections in $A$ and $B$ include spinal segments T9 and T10. The bar represents $500 \mu \mathrm{m}$; figures in $A$ and $B$ are of equal magnification. 
diographic reflection of muscarinic binding sites in our material varies slightly from the relative concentration determined quantitatively in vitro on cell membranes isolated from discrete regions of rat spinal cord by Kayaalp and Neff (1980). In their studies with the same ligand, the receptor density in the intermediate zone of thoracic cord was equivalent to that in the ventral horn. It is difficult to assess the extent to which the pattern in grain density affects the visual interpretation of our material.

The diffuse grain pattern in the IML produced by QNB binding in comparison to the concentrated patterns observed with $\left[{ }^{3} \mathrm{H}\right] \mathrm{pAC}$ suggests that the muscarinic receptors are located postsynaptically on neuronal perikarya and dendrites in the IML. This interpretation is supported in part by data from Kayaalp and Neff (1980) in which there was no change in receptor number or affinity after transection of the spinal cord (i.e., decentralization). Therefore, the muscarinic receptors are not likely to be located on terminals of descending systems. The lack of denervation supersensitivity in their experiment also suggests that the cholinergic innervation of the IML is from a source intrinsic to the spinal cord. Along these lines, the common distribution of muscarinic receptors to sympathoadrenal neurons and other neurons in the IML raises the possibility that muscarinic receptors may, in general, mediate an autoregulatory role of acetylcholine-containing preganglionic sympathetic neurons. Functionally, stimulation of muscarinic receptors on sympathoadrenal neurons would be inhibitory since a decrease in tyrosine hydroxylase activity in the adrenal gland was observed when muscarinic agents were administered to spinalized rats (Gagner et al., 1983).

The results of LSD binding were interesting when compared with previous studies of Holets and Elde (1982) combining immunohistochemistry and retrograde labeling with fast blue. The immunohistochemical data indicated that serotonergic fibers innervate sympathoadrenal neurons as well as other sympathetic preganglionic neurons in the IML; no qualitative difference in innervation of the sympathoadrenal neurons and other preganglionic neurons was noted. The results of the present study extend these observations of the serotonergic innervation of the IML by showing a higher density of serotonin-binding sites over fast blue-labeled cells than over other regions in the IML. Because the area of grain counting maximized sampling over the cell bodies, the autoradiographic data indicate that perikaryal serotonin receptors are higher over sympathoadrenal neurons than over other preganglionic neurons in the IML and suggest a greater responsiveness of these neurons to serotonin than other preganglionic neurons. That this observation was a result of grain counting attests to the importance of quantification in morphological studies and the sensitivity that can be achieved. Similar to muscarinic receptors, stimulation of serotonin receptors on sympthoadrenal preganglionic neurons is believed to be inhibitory (Quik and Sourkes, 1977; Gagner et al., 1983).

Although a perikaryal relationship of serotonin receptors with sympathoadrenal neurons was determined, this relationship was not visually apparent in the autoradiogram. We believe this is due to the location of the receptors on the cell membrane. Since the majority of fast blue-labeled cells in the spinal cord sections are in cross-section, and only ligand bound to the upper $2 \mu \mathrm{m}$ of the section surface will effectively contribute to latent image formation in the emulsion, the outline of the cell membrane would be difficult to appreciate visually in an autoradiogram. In contrast, autoradiograms of opiate-binding sites over dorsal root ganglion cells show grains clustered over neuronal perikarya (Ninkovic et al., 1982). Given that synapses in dorsal root ganglia are rare (Kayakar et al., 1981) and opiates have effects via receptors on primary afferent terminals (Gamse et al., 1979), the grains over these perikarya may reflect pack- aging of receptors within the cytoplasm for transport to a terminal location, while our data may reflect receptors located on the plasma membrane of the sympathoadrenal neurons.

DHM was the only ligand that did not exhibit specific binding in the IML that was greater than other regions of the gray matter. Since there was some specific binding, we cannot exclude the possibility that some opiate effects on preganglionic sympathetic neurons are mediated via $\mu$ receptors. However, given the density of enkephalin- (Holets and Elde, 1982) and dynorphin-immunoreactive terminals in the IML (V. S. Seybold, unpublished observations), it is more likely that opiate effects in this region may be mediated by $\delta$ or $\kappa$ receptors (Lord et al., 1977; Chavkin et al., 1982).

Distribution of neurotransmitter-binding sites in thoracic spinal cord. Each ligand used in this study revealed a unique pattern of binding sites in thoracic spinal cord, but they all demonstrated a striking concentration of binding sites in substantia gelatinosa. For the opiate agonist DHM, the substantia gelatinosa was the only area showing a high concentration of binding sites in the thoracic spinal cord. This observation is consistent with descriptions of autoradiographic results with other $\mu$ receptor ligands of cervical and lumbar rat spinal cord (Pert et al., 1976; Atweh and Kuhar, 1977; Pearson et al., 1980). The limited binding pattern across substantia gelatinosa observed in rat is in contrast to the pattern reported in monkey spinal cord where the density of opiate receptors appears to decrease gradually from lamina II to the ventral spect of lamina IV (Wamsley et al., 1982). The concentration of $\left[{ }^{3} \mathrm{H}\right] \mathrm{QNB}-$, $\left[{ }^{3} \mathrm{H}\right] \mathrm{LSD}-$, and $\left[{ }^{3} \mathrm{H}\right] \mathrm{pAC}$-binding sites also observed in substantia gelatinosa is consistent with the results of others at other levels of the spinal cord (pAC: Young and Kuhar, 1979b; LSD: Young and Kuhar, 1980; QNB: Wamsley et al., 1981). Since substantia gelatinosa is a region which is responsible for modulation of nociceptive information in the spinal cord, a uniform distribution of these sites throughout the levels of the cord would be expected. It is noteworthy that stimulation of these receptor types (with the exception of muscarinic receptors) in spinal cord causes analgesia (Yaksh, 1970; Hylden and Wilcox, $1983 \mathrm{a}, \mathrm{b})$.

The region around the central canal exhibited the next highest number of transmitter receptor types. In our studies, muscarinic, serotonergic, and $\alpha_{2}$-adrenergic binding sites all appeared in moderate concentrations in this region. This observation is consistent with reports at other levels of the spinal cord for muscarinic (Wamsley et al., 1981) and serotonergic binding sites (Young and Kuhar, 1980) and extends the preliminary observations of $\mathrm{pAC}$-binding sites in the spinal cord made by Young and Kuhar (1979b). Since the region around the central canal is beginning to be recognized as a site involved in spinal transmission of nociceptive stimuli (Fields et al., 1975, Honda and Perl, 1981; Nahin et al., 1983), the parallel distrihution of receptors between substantia gelatinosa and lamina $\mathrm{X}$ suggests serotonin, norepinephrine, and acetylcholine may have functions in this region of the spinal cord parallel to those in substantia gelatinosa. Curiously, then, a high density of $\mu$ receptors was not similarly observed in the region around the central canal. The fact that this region is rich in the endogenous opiate substances enkephalin (Hokfelt et al., 1977; Gibson et al., 1981) and dynorphin (V. S. Seybold, unpublished observation) indicates that the physiological effects of these substances may be mediated via a different opiate receptor subtype in this region. In addition to a sensory function, the region lateral to the central canal in thoracic spinal cord has an autonomic efferent function in that some sympathetic preganglionic neurons have been localized to this region (Schramm et al., 1975; Petras and Faden, 1978; Dalsgaard and Elfvin, 1979; Holets and Elde, 1982). Therefore, receptors in this region may also contribute to regulation of autonomic function. 
Of the four ligands studied, QNB was the only substance that revealed densities of binding sites in the ventral horn, and the density in this region was greater than in the dorsal and intermediate horn. The same relative distribution of muscarinic binding sites in rat spinal cord was observed autoradiographically by Wamsley and co-workers (1981) in cervical cord and biochemically by Kayaalp and Neff (1980) on membrane homogenates from several cord levels. Parallel to this association with motor neurons in the spinal cord, muscarinic receptors appear to be concentrated in regions of cranial nerve motor nuclei in the brainstem (Rotter et al., 1979; Wamsley et al., 1981). In contrast to their correlation with efferent motor function, there was a striking paucity of muscarinic receptors in nucleus dorsalis of Clarke, a sensory nucleus.

In summary, significant densities of $\alpha_{2}$-adrenergic, serotonergic, and muscarinic receptors have been localized over the perikaryal zone of sympathoadrenal neurons in rat spinal cord. These findings suggest that adrenergenic and serotonergic input to the IML in spinal segments T7 to T10 is preferentially targeted upon sympathoadrenal neurons. In contrast, muscarinic and opiate $(\mu)$ binding sites were present over the perikaryal zone of sympathetic preganglionic neurons but were neither preferentially enriched or less abundant over sympathoadrenal neurons.

\section{References}

Atweh, S. F., and M. J. Kuhar (1977) Autoradiographic localization of opiate receptors in rat brain. I. Spinal cord and lower medulla. Brain Res. 124: 53-67.

Bennett, J. P., and S. H. Snyder (1975) Stereospecific binding of Dlysergic acid diethylamide (LSD) to brain membrane: Relationship to serotonin receptors. Brain Res. 94: 523-544.

Burt, D. R., I. Creese, and S. H. Snyder (1976) Binding interactions of lysergic acid diethylamide and related drugs with dopamine receptors in the brain. Mol. Pharmacol. 12: 631-638.

Chavkin, C., I. F. James, and A. Goldstein (1982) Dynorphin is a specific endogenous ligand of the kappa opioid receptor. Science 215: 413-415.

Connor, H. E., and L. Finch (1981) Postsynaptic spinal $\alpha$-adrenoreceptors mediate effects of intrathecal clonidine. Eur. J. Pharmacol. 76: 97-100.

Cummings, J. F. (1969) Thoracolumbar preganglionic neurons and adrenal innervation in the dog. Acta Anat. 73: 27-37.

Dalsgaard, C. -J., and L. -G. Elfvin (1979) Spinal origin of preganglionic fibers projecting onto the superior cervical ganglion and inferior mesenteric ganglion of the guinea pig, as demonstrated by the horseradish peroxidase technique. Brain Res. 172: 139-143.

Deuschl, G., and M. Illert (1981) Cytoarchitectonic organization of lumbar preganglionic sympathetic neurons in the cat. J. Autonom. Nerv. Syst. 3: 193-213.

Fields, H. L., G. M. Wagner, and S. D. Anderson (1975) Some properties of spinal neurons projecting to the medial brain-stem reticular formation. Exp. Neurol. 47: 118-134.

Fields, H. L., P. C. Emson, B. K. Leigh, R. F. T. Gilbert, and L. L. Iversen (1980) Multiple opiate receptor sites on primary afferent fibres. Nature 284: 351-353.

Gagner, J. P., S. Gauthier, and T. L. Sourkes (1983) Participation of spinal monoaminergic and cholinergic systems in the regulation of adrenal tyrosine hydroxylase. Neuropharmacology 22: 45-53.

Gamse, R., P. Holzer, and F. Lembeck (1979) Indirect evidence for presynaptic location of opiate receptors on chemosensitive primary sensory neurones. Arch. Pharmacol. 308: 281-285.

Gauthier, S., J. -P. Gagner, and T. L. Sourkes (1979) Role of descending spinal pathways in the regulation of adrenal tyrosine hydroxylase. Exp. Neurol. 66: 42-54.

Gibson, S. J., J. M. Polak, S. R. Bloom, and P. Wall (1981) The distribution of nine peptides in rat spinal cord with special emphasis on the substantia gelatinosa and on the area around the central canal (lamina X). J. Comp. Neurol. 201: 65-79.

Glazer, E. J., and L. L. Ross (1980) Localization of noradrenergic terminals in sympathetic preganglionic nuclei of the rat: Demonstration by immunohistochemical localization of dopamine- $\beta$-hydroxyl- ase. Brain Res. 185: 39-49.

Hiller, J. M., E. J. Simon, S. M. Crain, and E. R. Peterson (1978) Opiate receptors in cultures of fetal mouse dorsal root ganglia (DRG) and spinal cord: Predominance in DRG neurites. Brain Res. 145: 396-400.

Hokfelt, T., R. Elde, O. Johansson, L. Terenius, and L. Stein (1977) The distribution of enkephalin-immunoreactive cell bodies in the rat central nervous system. Neurosci. Lett. 5: 25-31.

Holets, V., and R. Elde (1982) The differential distribution and relationship of serotoninergic and peptidergic fibers to sympathoadrenal neurons in the intermediolateral cell column of the rat: A combined retrograde axonal transport and immunofluorescence study. Neuroscience 7: 1155-1174.

Honda, C. N., and E. R. Perl (1981) Properties of neurons in lamina X and the midline dorsal horn of the sacrococcygeal spinal cord of the cat. Soc. Neurosci. Abstr. 7: 610.

Hylden, J. L., and G. L. Wilcox (1983a) Pharmacological characterization of substance $\mathrm{P}$-induced nociception in mice: Modulation by opioid and noradrenergic agonists at the spinal level. J. Pharmacol. Exp. Ther. 226: 398-404.

Hylden, J. L., and G. L. Wilcox (1983b) Intrathecal serotonin in mice: Analgesia and inhibition of a spinal action of substance P. Life Sci. 33: 789-795.

Kayaalp, S. O., and N. H. Neff (1980) Regional distribution of cholinergic muscarinic receptors in spinal cord. Brain Res. 196: 429-436.

Kayakar, T., J. Takimoto, and S. Sakashita (1981) Synaptic functions in the cat spinal ganglion. Brain Res. 216: 277-290.

LaMotte, C., C. B. Pert, and S. H. Snyder (1976) Opiate receptor binding in primate spinal cord: Distribution and changes after dorsal rool section. Brain Res. 112: 407-412.

Lewander, T., T. H. Joh, and D. Reis (1977) Tyrosine hydroxylase: Delayed activation in central noradrenergic neurons and induction in adrenal medulla elicited by stimulation of central cholinergic receptors. J. Pharmacol. Exp. Ther. 200: 523-534.

Lord, J. A. H., A. A. Waterfield, J. Hughes, and H. W. Kosterlitz (1977) Endogenous opid peptides: Multiple agonists and receptors. Nature (Lond.) 267: 495-499.

Maycock, W. A., and T. S. Heslop (1979) An experimental investigation of the nerve supply of the adrenal medulla of the cat. J. Anat. 73: $551-558$

Meibach, R. C., S. Maayani, and J. P. Green (1980) Characterization and radioautography of $\left({ }^{3} \mathrm{H}\right)$ LSD binding by rat brain slices in vitro: The effect of 5-hydroxytryptamine. Eur. J. Pharmacol. 67: 371-382.

Meyerhofer, A. (1972) Absolute configuration of 3-quinuclidinyl benzilate and the behavioral effect in the dog of the optical isomers. J. Med. Chem. 15: 994-995.

Monroe, P. J., and D. J. Smith (1983) Characterization of multiple $\left[{ }^{3} \mathrm{H}\right] 5$-hydroxytryptamine binding sites in rat spinal cord tissue. J. Neurochem. 41: 349-355.

Nahin, R. L., A. M. Madsen, and G. J. Giesler, Jr. (1983) Anatomical and physiological studies of the gray matter surrounding the spinal cord central canal. J. Comp. Neurol. 220: 321-335.

Ninkovic, M., S. P. Hunt, and J. R. W. Gleave (1982) Localization of opiate and histamine $\mathrm{H}_{1}$-receptors in primate sensory ganglia and spinal cord. Brain Res. 241: 197-206

Pearson, J., L. Brandeis, E. Simon, and J. Hiller (1980) Radioautography of binding of tritiated diprenorphine to opiate receptors in the rat. Life Sci. 26: 1047-1052.

Peroutka, S. J., and S. H. Snyder (1979) Multiple serotonin receptors: Differential binding of $\left[{ }^{3} \mathrm{H}\right] 5$-hydroxytryptamine, $\left[{ }^{3} \mathrm{H}\right]$ lysergic acid diethylamide and $\left[{ }^{3} \mathrm{H}\right]$ spiroperidol. Mol. Pharmacol. 16: 687-699.

Pert, C. B., M. J. Kuhar, and S. H. Snyder (1976) Opiate receptor: Autoradiographic localization in rat brain. Proc. Natl. Acad. Sci. U. S. A. 73: 3729-3733.

Petras, J. M., and J. F. Cummings (1972) Autonomic nucleus in the spinal cord of the rhesus monkey: A correlation of the findings of cytoarchitectonics and sympathectomy and fiber degeneration following dorsal rhizotomy. J. Comp. Neurol. 146: 189-218.

Petras, J. M., and A. J. Faden (1978) The origin of sympathetic preganglionic neurons in the dog. Brain Res. 144: 353-357.

Quik, M., and T. L. Sourkes (1977) Central dopaminergic and serotoninergic systems in the regulation of adrenal tyrosine hydroxylase. J. Neurochem. 28: 137-147.

Rethelyi, M. (1972) Cell and neuropil architecture of the intermediolateral (sympathetic) mucleus of cat spinal cord. Brain Res. 46: 203213. 
Rotter, A., N. J. M. Birdshall, P. M. Field, and G. Raisman (1979) Muscarinic receptors in the central nervous system of the rat. II. Distribution of binding of $\left.{ }^{3} \mathrm{H}\right]$ propylbenzilycholine mustard in the midbrain and hindbrain. Brain Res. Rev. 1: 167-183.

Kouot, B. K., and S. H. Snyder (1979) $\left.{ }^{3} \mathrm{H}\right]$ para-Amino-clonidine: A novel ligand which binds with high affinity to $\alpha$-adrenergic receptors. Life Sci. 25: 769-774.

Schramm, L. P., J. R. Adair, J. M. Stribling, and L. P. Gray (1975) Preganglionic innervation of the adrenal gland of the rat: $\mathrm{A}$ study using horseradish peroxidase. Exp. Neurol. 49: 540-553.

U'Prichard, D. C., and S. H. Snyder (1979) Distinct $\alpha$-noradrenergic receptors differentiated by binding and physiological relationships. Life Sci. 24: 79-88.

U'Prichard, D. C., W. D. Bechtel, B. M. Rouot, and S. H. Snyder (1979) Multiple apparent alpha-noradrenergic receptor binding sites in rat brain: Effect of 6-hydroxydopamine. Mol. Pharmacol. 16: 47-60.

Wamsley, J. K., M. S. Lewis, W. S. Young, III, and M. J. Kuhar (1981) Autoradiographic localization of muscarinic cholinergic receptors in rat brainstem. J. Neurosci. 1: 176-191.

Wamsley, J. K., M. A. Zarbin, W. S. Young, III, and M. J. Kuhar (1982) Distribution of opiate receptors in the monkey brain: An autoradiographic study. Neuroscience 7: 595-613

Westlund, K. N., R. M. Bowker, M. G. Ziegler, and J. D. Coulter (1983) Noradrenergic projections to the spinal cord of the rat. Brain Res. 263: 15-31.

Wood, P. L., S. E. Charleson, D. Lane, and R. L. Hudbin (1981) Multiple opiate receptors: Differential binding of $\mu, \kappa$, and $\delta$ agonists. Neuropharmacology 20: 1215-1220.

Yaksh, T. L. (1970) Direct evidence that spinal serotonin and noradrenaline terminals mediate the spinal antinociceptive effects of morphine. Brain Res. 160: 180-185.

Yamamura, H. I., and S. H. Snyder (1974) Muscarinic cholinergic binding in rat brain. Proc. Natl. Acad. Sci. U. S. A. 71: 1725-1729.

Young, W. S., III, and M. J. Kuhar (1979a) A new method for receptor autoradiography: $\left[{ }^{3} \mathrm{H}\right]$ Opioid receptors in rat brain. Brain Res. 179: $255-270$.

Young, W. S., III, and M. J. Kuhar (1979b) Noradrenergic $\alpha_{1}$ and $\alpha_{2}$ receptors: Autoradiographic visualization. Eur. J. Pharmacol. 59: 317-319.

Young, W. S., III, and M. J. Kuhar (1980) Serotonin receptor localization in rat brain by light microscopic autoradiography. Eur. J. Pharmacol. 62: 237-239. 